\title{
Perbedaan Awitan Pubertas pada Anak Perempuan di Perkotaan dan Pedesaan
}

\author{
Syamsul Azwar, Rita E. Rusli, Khainir Akbar, Charles D. Siregar, Hakimi.
}

\begin{abstract}
Rerata awitan pubertas pada anak perempuan terjadi pada usia 11 tahun dengan rentang usia antara 8-13 tahun. Awitan pubertas didapati berbeda pada anak perempuan yang tinggal di perkotaan dan pedesaan. Tujuan penelitian ini untuk mengetahui perbedaan rerata awitan pubertas pada anak perempuan perkotaan dan pedesaan. Penelitian ini dilakukan secara cross sectional study pada murid perempuan Sekolah Dasar Al-Azhar Kotamadya Medan (perkotaan) dan murid Sekolah Dasar Negeri Nomor 050577 Binjai (pedesaan). Dilakukan pemeriksaan tingkat perkembangan payudara pada kedua subyek berdasarkan skala Tanner. Analisis statistik menggunakan Student t-test dengan tingkat kemaknaan $p<0,05$. Diantara sampel pada 99 anak, awitan pubertas pada anak perempuan perkotaan pada usia 8, 9, 10, 11, dan 12 tahun berturut turut 12,1\%; 23,2\%; 33,3\%; 27,3\%; dan 4,0\% dengan rentang usia 8-12 tahun. Pada anak perempuan pedesaan pubertas didapatkan pada usia 9, 10, 11, 12, dan 14 tahun berturut-turut $1,0 \% ; 13,1 \% ; 30,3 \% ; 29,3 \%$; dan 7,1\% dengan rentang usia $9-14$ tahun. Rerata usia awitan pubertas pada anak perempuan perkotaan 9,88 \pm 1,07 dan pada anak perempuan pedesaan 11,74 $\pm 1,16$ tahun. Terdapat perbedaan yang bermakna antara rerata awitan pubertas anak perempuan perkotaan dan pedesaan, demikian pula antara status gizi antara anak perempuan perkotaan dan pedesaan. Kesimpulan, awitan pubertas lebih cepat dialami anak perkotaan dibanding anak perempuan pedesaan.
\end{abstract}

Kata kunci: pubertas, skala tanner,tingkat maturitas kelamin (TMK)

P ubertas adalah periode lengkapnya proses pematangan seksual dengan hasil tercapainya kemampuan reproduksi. ${ }^{1,2}$ Pubertas dimulai dengan munculnya karakteristik kelamin sekunder (perkembangan payudara rambut pubis dan rambut ketiak). ${ }^{1-11,13}$ Tanda pubertas yang pertama yang pertama muncul pada wanita adalah tunas payudara. ${ }^{1-}$ ${ }^{6}$ Perkembangan rambut pubis baru dimulai 6 bulan setelah perkembangan payudara. ${ }^{1}$

Tingkat kematangan seksual dapat dinilai dengan skala Tanner, ${ }^{1-8}$ yang membagi tingkat kematangan

Alamat korespondensi:

Dr. Syamsul Anwar, Sp.A.

Bagian Ilmu Kesehatan Anak - Fakultas Kedokteran Universitas Sumatera Utara / RS H. Adam Malik, Jl. Bunga Lau No.17 Medan.

Telepon: 061-8360143, 8360405, 836034 Fax: 061-8361721. seksual (tingkat maturitas kelamin) dalam lima tingkatan berdasarkan perkembangan payudara dan rambut pubis). ${ }^{1-6}$ Awitan pubertas didefinisikan sebagai tingkat maturitas kelamin dua (TKM 2) pada skala Tanner. ${ }^{1-11}$

Telah banyak dilakukan penelitian mengenai usia awitan pubertas pada wanita ${ }^{1-6}$ tetapi pada wanita Indonesia belum pernah dilakukan. Dari beberapa penelitian terdahulu ditemukan rerata usia awitan pubertas. Pubertas tidak sama pada setiap bangsa dan cenderung berubah dari waktu ke waktu. Beberapa faktor yang dianggap mempengaruhi pubertas adalah status gizi, kelembaban, iklim, musim, paparan cahaya, dan ketinggian) dan keadaan psikologi. . $^{2,46}$

Tujuan penelitian ini untuk mengetahui rerata usia awitan pubertas pada wanita dan mengetahui apakah ada perbedaan usia awitan pubertas pada wanita yang tinggal di perkotaan dan pedesaan. 


\section{Bahan dan Cara}

Penelitian ini dilakukan secara cross sectional. Sampel penelitian adalah murid perempuan Sekolah Dasar AlAzhar Kotamadya Medan (perkotaan) dan murid perempuan Sekolah Dasar Negeri Nomor 050577 Binjai (pedesaan). Pemilihan sekolah perkotaan dan pedesaan ditetapkan secara purposive sampling. ${ }^{14}$ Untuk membedakan daerah perkotaan dan pedesaan dipakai indikator komposit (indikator gabungan) yang ditetapkan Badan Pusat Statistik Nasional Tahun 2000. Skor atau nilai-nilainya didasarkan pada skor atau nilai kepadatan penduduk, persentase rumah tangga yang mempunyai telepon dan listrik (PLN atau non PLN) dan fasilitas utama (fasilitas perkotaan). Suatu daerah disebut perkotaan apabila skor lebih besar atau sama dengan $10(\geq 10)$ dan disebut pedesaan apabila skor lebih kecil dari $10(<10) .{ }^{12}$ Kriteria inklusi adalah murid perempuan yang pada saat pemeriksaan berada pada tingkat maturitas kelamin dua atau lebih skala Tanner dan telah mendapat izin orangtua. Kriteria eksklusi adalah pelajar putri dengan kelainan payudara, pubertas prekokis (usia kurang 8 tahun) dan yang menolak ikut penelitian. Dilakukan penentuan tingkat maturitas kelamin dengan melakukan pemeriksaan tingkat perkembangan payudara berdasarkan skala Tanner. Umur dihitung dalam tahun berdasarkan akte kelahiran atau catatan kelahiran lainnya. Berat badan ditimbang dengan menggunakan timbangan merk SECA dengan sensitifitas $0,1 \mathrm{~kg}$. Panjang badan diukur dengan Microtoise dengan sensitifitas $0,1 \mathrm{~cm}$. Status gizi diterapkan berdasarkan standar NCHS (National Center for Health and Statistic).

\section{Hasil}

Dari 195 murid perempuan Sekolah Dasar Al-Azhar (perkotaan) yang diperiksa didapati 102 murid sudah mengalami pubertas, 3 orang dikeluarkan karena usia kurang dari 8 tahun. Sedangkan pada murid SD Nomor 050577 (pedesaan) dari 217 jumlah murid perempuan yang diperiksa 104 orang sudah mengalami pubertas, 5 orang dikeluarkan karena tidak didapati catatan kelahiran yang jelas. Maka jumlah murid yang ikut penelitian adalah $99(50,8 \%)$ murid perempuan SD Al-Azhar dan 99 (45,6\%) murid dari SD 050577. Perbedaan rerata usia awitan pubertas pada kedua kelompok dapat dilihat Tabel 1.
Tabel 1. Perbedaan rerata usia awitan pubertas pada kedua kelompok

\begin{tabular}{lll}
\hline Lokasi & Rerata \pm SD & $\rho$ \\
\hline Perkotaan & $9,88 \pm 1,07$ & \\
Pedesaan & $11,7+1,16$ & 0,00 \\
\hline
\end{tabular}

*SD : Standar Deviasi

Dari tabel 1 didapati yang bermakna $(p<0,05)$ antara rerata usia awitan pubertas pada murid perempuan perkotaan dan pedesaan. Murid perempuan perkotaan lebih cepat mengalami pubertas dibanding murid perempuan pedesaan.

Dari 99 murid perempuan SD Al-Azhar yang diperiksa didapati usia awaitan pubertas pada usia 8,9 , 11 , dan 12 tahun, berturut-turut 12,1\%; 23,2\%; $33,3 \% ; 27,3 \%$; dan $4,0 \%$ dengan rentang usia antara 8 12 tahun. Pada murid perempuan SD Nomor 050577 awitan pubertas pada usia 9, 10,11,12,13 dan 14 tahun, berturut-turut $1,0 \% ; 13,1 \% ; 30,3 \% ; 29,3 \%$; dan $7,1 \%$ dengan rentang usia 9-14 tahun. Distribusi umur awitan pubertas pada kedua kelompok dapat dilihat pada Gambar 1:

Dari Gambar 1 terlihat pada kelompok perkotaan usia awitan pubertas paling banyak terjadi pada usia 10 tahun $(33,3 \%)$ sedangkan pada kelompok pedesaan awitan pubertas paling banyak terjadi pada usia 11 tahun $(30,3 \%)$.

Dari Tabel 2 didapatkan hubungan yang bermakna

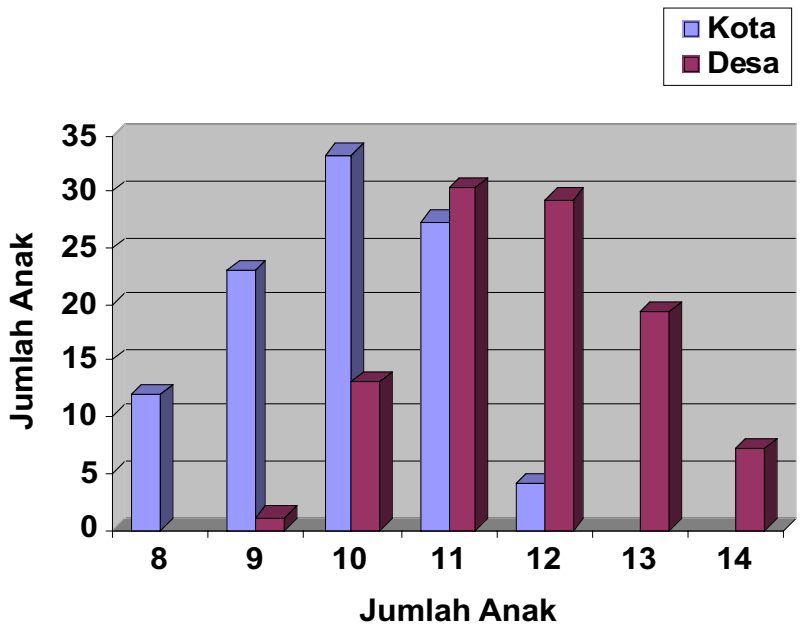

Gambar 1. Distribusi umur awitan pubertas pada murid perempuan perkotaan dan pedesaan 
Sari Pediatri, Vol. 3, No. 2, September 2001

Tabel 2. Perbedaan status gizi pada kedua kelompok

\begin{tabular}{lllll}
\hline Status Gizi & \multicolumn{2}{c}{ Perkotaan } & \multicolumn{2}{l}{ Pedesaan } \\
\cline { 2 - 5 } & $\mathrm{n}$ & $\%$ & $\mathrm{n}$ & $\%$ \\
\hline KKP $^{*}$ & 21 & 21,2 & 50 & 50,5 \\
Gizi baik & 78 & 78,8 & 49 & 49,5 \\
\hline Jumlah & 99 & 100 & 99 & 100
\end{tabular}

${ }^{*} \mathrm{KKP}$ : kurang kalori protein

$\mathrm{p}<0,005)$ status gizi pada murid perempuan perkotaan dan pedesaan. Didapati kurang protein sebanyak 21 $(21,2 \%)$ dan gizi baik $78(78,8 \%)$ di perkotaan dibanding $50(50,5 \%)$ dan $49(49,5 \%)$ di pedesaan.

\section{Diskusi}

Sampai saat ini skala Tanner (1999) merupakan alat yang dianggap paling akurat untuk menilai tingkat maturitas kelamin. ${ }^{11}$ Tanner membagi tingkat maturitas kelamin dalam 5 tingkatan berdasarkan perkembangan payudara dan rambut pubis, maka pubertas didefinisikan sebagai tingkat maturitas kelamin dua (TMK2) pada skala Tanner. Pada penelitian ini penilaian tingkat maturitas kelamin hanya didasarkan pada perkembangan payudara, penilaian perkembangan rambut pubis tidak dilakukan. Hennenberg CM dkk mendapatkan 93\% nilai ketepatan penentuan pubertas dengan hanya menilai perkembangan payudara pada skala Tanner 3 . Tunas payudara merupakan tanda pubertas yang pertama muncul, sedangkan rambut pubis baru terlihat 6 bulan setelah perkembangan payudara.

Lee PA. mendapatkan rerata usia awitan pubertas pada wanita 11 tahun dengan rentang antara 8-13 tahun. ${ }^{1}$ Irwin mendapatkan rerata awitan pubertas pada wanita 11,2 tahun dengan rentang usia antara 813 tahun. ${ }^{8}$ Marshall dan Tanner mendapatkan 95\% tanda pubertas timbul pada usia 8,3 - 13 tahun. $^{7}$ Needlman mendapatkan perkembangan payudara hanya pada 3\% anak (TMK 2) sebelum usia 8,9 tahun, dan $97 \%$ anak usia 12,9 tahun. ${ }^{9}$ Pada penelitian ini didapati rerata usia awitan pubertas pada murid perempuan perkotaan $9,88 \pm 1,07$ dengan rentang usia 8-12 tahun. Sedangkan rerata usia awitan pubertas pada murid perempuan pedesaan $11,74 \pm 1,16$ dengan rentang usia 9-14 tahun. Zacharias dan Wurtman yang melakukan penelitian pada daerah urban dan rural di
Ceylon mendapatkan bahwa wanita yang tinggal di daerah urban lebih cepat mengalami maturasi seksual dibandingkan daerah rural. ${ }^{6}$ Rebar mendapatkan anak perempuan perkotaan lebih cepat mengalami pubertas dibanding anak perempuan pedesaan. ${ }^{2}$ Penelitian Hennenberg dan Vismanos B. ${ }^{3}$ yang menggunakan perkembangan payudara dan kurva tinggi mendapatkan usia awitan pubertas paling banyak ditemukan pada usia 11 tahun $(33,1 \%)$ dan $32,5 \%$ pada usia 10 tahun. Pada penelitian ini usia awitan pubertas paling banyak ditemukan pada usia 10 tahun di daerah perkotaan $(33,3 \%)$ dan usia 11 tahun $(30,3 \%)$ di pedesaan. Pada penelitian ini didapati adanya perbedaan yang bermakna antara status gizi murid perempuan perkotaan dan pedesaan hal ini sebanding dengan tingkat status gizi murid perempuan perkotaan lebih baik dibanding pedesaan. Beberapa faktor yang dapat mempengaruhi pubertas adalah status gizi, sosioekonomi, kesehatan umum, geografik (temperatur, kelembaban, iklim, musim, paparan cahaya, dan ketinggian) dan keadaan psikologi. ${ }^{2,4,6}$ Zacharias L dan Wurtman ${ }^{6}$ menduga adanya perbedaan awitan pubertas pada perempuan perkotaan dan pedesaan disebabkan karena faktor gizi. Higiene yang lebih baik, tingginya stimulai seksual, dan keadaan sosial pada perempuan perkotaan mungkin merupakan salah satu faktor penyebab. Prawirohardjo dkk mendapatkan bahwa adanya perbedaan usia awitan pubertas di perkotaan dan pedesaan disebabkan karena faktor kesehatan umum dan gizi yang lebih baik pada wanita perkotaan. ${ }^{4}$

Perlu dilakukan penelitian lebih lanjut dengan jumlah sampel yang lebih banyak yang dapat mewakili seluruh populasi dan perlu dilakukan penelitian yang menyeluruh untuk mendapatkan nilai baku usia awitan pubertas pada wanita Indonesia. Sebagai kesimpulan, didapatkan perbedaan yang bermakna rerata pubertas pada anak perempuan perkotaan dan pedesaan. Anak perempuan perkotaan lebih cepat mengalami pubertas dibanding anak perempuan pedesaan.

\section{Daftar Pustaka}

1. Lee PA. Disorders of Peberty. Dalam : Lifshitz F. Pediatric endocronology. Edisi ke-3. New York: Marcel Dekker Inc, 1996. h. 175-80.

2. Rebar RW. Puberty. Dalam : Berek JS, Adaski EY, Hillard PA, penyunting, Novak's Gynecology. Edisi ke-8. Philadelphia: William \& Wilkins, 1996. h. 771-74. 
3. Hennenberg CM, Vizmanos B. The duration of puberty in girls is related to the timing of its onset. J Pediatr 1996 ; 131:518-621.

4. Prawirohardjo S, Wiknjosastro H, Sumapraja S, Saefuddin AB. Ilmu Kandungan, Bina Rupa Aksara, Jakarta, Cetakan ke 5, 1991. h. 367-69.

5. Beckmenn CRB, Ling MD, Barzansky BM, dkk. Obstetrics and Gynecology, Edisi ke -2, Philadelphia: William \&Wilkins, 1995. h. 367-69.

6. Zacharias L, Wurtman RJ. Age at menarche, New Engl J Med., 1969 ; 280:868 - 74 .

7. Marshall WA, Tanner JM. Variation in pattren of pubertal changes in girls. Arch Dis Child, 1969 : 291. h. 291-303.

8. Irwin CE. The Adolescent patient. Dalam : Rudolph AM, Hoffman JIE, Rudolph CD, penyunting. Rudolph's Pediatrics. Edisi ke-20, London: Hall International, 1996. h. 37-9.
9. Needlman RD. Growth And Development. Dalam: Behrman RE, Kligman RM, Arvin AM, penyunting. Nelson Textbook Pediatric, Edisi ke 15: Philadelphia: Saunders, 1996. h. 58-63.

10. Markum AH dkk. Buku Ajar Ilmu Kesehatan Anak, Jakarta Balai Penerbit FKUI, Edisi ke-1, 1991. h. 2931 .

11. Tanner JM. Growth at adolescence, Edisi ke-2, Oxford. Blackwell Scientific Publications, 1962. h. 97-101.

12. Bagian Statistik Kesejahteraan Rumah Tangga. Statistik kesejahteraan rakyat, Biro Statistik Jakarta 2000. h. 5-6.

13. Ridder CMD dkk. Body fat mass, body fat distribution, and pubertal development. A longitudinal study of physical and hormonal sexual maturation of girls. J Clin Endocrine Metab 1992; 75:442-6.

14. Notoatmodjo S. Metodologi penelitian kesehatan, Cetakan Ke-1. Jakarta: Rineka Cipta, 1993. h. 84. 